いる。その変化の速度は 14-1200 から 14-1500 の方向に最も速 く6-1400 から 12-1800 の方向には特そい。

図 8 と図 9 をかさねて見ると, $\mathrm{UO}_{2}$ と UC が共存する範囲が わかり, 温度の上年とともに $\mathrm{UO}_{2}$ は減少し, 逆に UC は増加す る。図 9 と図 10 をかさねて見ると同様に UC と $\mathrm{UC}_{2}$ の共存範 囲がわかる。炭素量が 10\% 以下の試料では，その温度範囲は $1200 \sim 1600^{\circ} \mathrm{C}$ であるが, 炭素量が增加すると温度範囲はまし, 炭素が $13 \%$ 程度では $1900^{\circ} \mathrm{C}$ 付近までで両者は共存する。さら に炭素量が増すと共存温度範囲 $1200 \sim 1600^{\circ} \mathrm{C}$ まで低下するが, $15 \%$ 以上 $16 \%$ 以下では再び大きく増加する。これは前述したよ $5 に, \mathrm{UC}$ と $\mathrm{UC}_{2}$ が固溶して固溶体をつくり, 冷却時再び UC
と $\mathrm{UC}_{2}$ に解離析出したためである8,9)。低炭素試料では $\mathrm{UC}_{2}$ の 濃度に最大值があり，その温度は炭素量の增加につれて $1400^{\circ} \mathrm{C}$ から $1450^{\circ} \mathrm{C}$ へと上年し, 炭素量は $15.5 \%$ 以上飞なると UC 濃 度に最大值があらわれる。その温度す 1400 1450ㄷ C である。UC および $\mathrm{UC}_{2}$ 間の変化の速度は 15-1900 から 16-1900 の方向で 最も速い。またこの両者は $1200^{\circ} \mathrm{C}$ 付近の温度でほとんど同時に 生成するが，固相反応の立場から $\mathrm{UO}_{2}$ から UC となり，ついで $\mathrm{UC}$ は直ちに $\mathrm{UC}_{2}$ に変化すると考えた方が妥当と思われる。

(昭和 34 年 4 月, 日化 12 年会講演)

本研究は昭和 32 年度文部省機関研究費によって行なったもの である。ここに記して梁甚の謝意を表する。

\title{
X 線回折法によるケイ酸塩，カララスのナトリウム，カリウムの定量方法
}

(昭 和 35 年 8 月 16 日 受 理)

\author{
平野 四·蔵・貴家 恕夫*
}

\begin{abstract}
ケイ酸塩，ガラス等の試料をフッ化水素酸で分解し，過塩素酸を加えて加熱蒸発してケイ酸を揮散させ，生成した過塩 素酸塩を 500 ～ $600^{\circ} \mathrm{C}$ で熱分解して，ナトリウム，カリウムをぞれぞれ塩化ナトリウム，塩化カリウムの形に変えたのち 石英あるいはフッ化バリウムを内標準物質としてX線回折計を用いてソーダガラス, 硬質ガラス, 長石等の試料中のナト リウム，カリウムの定量を行なって Lawrence Smith 法，および炎光光度法によって定量した值と比較した。

定量值の再現性は良好で, '重量法や炎光光度法で定量した值とよく一致した。Lawrence Smith 法のような重量法に比 較して幾分精度は劣るが操作が簡単で比較的短時間にナトリウム，カリウムの同時定量が出来た。
\end{abstract}

\section{1 緒言}

ケイ酸塩, ガラス等のナトリウム, カリウムの定量方法には Lawrence Smith 法1), Berzelius 法1,4)，拈よびこれらの改良方 法 $2,3,5,6)$, 炎光光度法, その他迅速分析方法 ${ }^{8}$ 《関する研究があ る。重量分析方法は精度はよいが操作が複雑で熟練を要し, 操作 に長時間を要する。著者は従来行なわれている不溶性ケイ酸塩, ガラス中のアルカリ定量のための分解方法で試料を分解して, 分 解生成物中のナトリウム, カリウムの化合状態を調查し, X線回 折計による定量方法を決定した。

\section{2 装置および試薬}

\section{$2 \cdot 1$ 装置}

* 東京大学工学部応用化学科工業分析化学教室 : 東京都文京 区本富士町.

1). W.F. Hillebrand, G.E. F. Lundell, H. A. Bright, J. L. Hoffman, "Applied Inorganic Analysis" 2 nd Ed. p. 923 (1953).

2) P. J.Eloving, P. C. Cho, Anal. Chem. 21, 507 (1949).

3) E. R. Stevens, Ind. Eng. Chem. Anal. Ed. 12, 413 (1940).

4) J. J. Berzelius, Poyg. Ann. 1, 169 (1824).

5) F. W. Glaze, J. Am. Ceram. Soc. 14, 450 (1931).

6) G. G. Marvin, L. B. Woolaver, Ind. Eng. Chem. Anal. Ed. 17, 554 (1945).

7) G. G. Marvin, L. B. Woolaver, Ind. Eng. Chem. Anal. Ed. 17, 474 (1945).

8）新海, 窵協誌 58,90 (1950).
X線回折計：理学電機株式会社ガイガーフレックスを使用し， $\mathrm{X}$ 線は $\mathrm{CuK}_{\alpha}$ あるいは $\mathrm{CoK}_{\alpha}$ を使用した。 炎光光度計：東京光電株式会社 ANA-10 型炎光光度計を使用 した。

\section{$2 \cdot 2 \mathrm{X}$ 線回折用標準物質}

塩化ナトリウム，塩化カリウムは特級試薬を粉硉して 325 メッ シュフルイを通過させたのち $100^{\circ} \mathrm{C} て ゙$ 乾燥した。

フッ化バリウムは 1 級フッ化パリウムを電気炉内で約 2 時間, 約 $1000^{\circ} \mathrm{C}$ に加熱したのち粉磁して 325 メッシュフルイを通過 させた。

石英は純粋な水晶を粉啸して 325 メッシュフルイを通過させた あのをメノウ乳鉢を用いて更に 20～30 分間粉砕した。

な扣上記標準物質はX線回折計を用いて測定した結果いずれる 不純物の存在を認めなかった。

\section{3 試料分解方法の検討}

不溶性ケイ酸塩, ガラス等の試料の分解方法であるフッ化水素 酸-硫酸分解法 ${ }^{1,2)}$ ，フッ化水素酸-過塩素酸分解法 $\left.8,6,7,9\right)$, 現在あ まり用いられないがフッ化水素酸ーシュウ酸分解法 ${ }^{10)}$ ，および忒 速分析方法に用いるフッ化水素酸分解法 ${ }^{8)}$ で試料を分解し， X 線 回折計を用いて組成分析を行なって，ナトリウム，カリウムの化 合状態を調査した結果, 過塩素酸ーフッ化水素酸分解以外の方法

9) H. H. Willard, Ind. Eng. Chem. Anal. Ed. 15, 234 (1942).

10) E. C. Sullivan, W. C. Tayler, J. Ind. Eng. Chem. 6, 897 (1914). 
で試料を分解したときは, 固溶体あるいは複塩を生じ, ナトリウ ム，カリウムの単独の化合物を生じなかった。

ガラス，長石等のケイ酸塩をフッ化水素酸一過塩素酸で分解し たのち，砂亚上で蒸発乾固してケイ酸执よび過剩の過塩素酸をお いだすと, ガラス, 長石等の中に含まれている。ナトリウム, カ リウム, カルシウム, マグネシウム, 鉄, アルミニウム, 等はい ずれす過塩素酸塩となる。Marvin, Woolaver6,7) らの過塩素酸の 熱分解に関する報告によると，ナトリウム，カリウム，リチウ ム，の過塩素酸塩は $500^{\circ} \mathrm{C}$ 前後でいずれも酸素を放出してそれそ れ塩化物に, カルシウムの過塩素塩は塩基性塩化物に, 鉄, マグ ネシウム, アルミニウムの過塩素酸塩はまず結合水によって加水 分解したのち過塩素酸を放出して $500^{\circ} \mathrm{C}$ 前後の温度で完全に酸化 物の形になる。よって著者らはガラス, 長石等に含まれていると 考えられる化合物をフッ化水素酸一過塩素酸で分解して過塩素酸 塩とし，これを $500 \sim 600^{\circ} \mathrm{C}^{6,7)}$ で熱分解し，分解生成物の組成分 析をX線回折計を用いて行なった。

\subsection{X 楾回折計による粗成分折}

（1）塩化ナトリウム, 塩化カリウムの等量混合物，（2）炭酸 マグネシウム，（3）水酸化アルミニウム，（4）金属チタンにそ れぞれ無水ケイ酸を混合し，これらをフッ化水素酸-過塩素酸で 処理分解した生成物のX線回折図をまとめて図 1 亿示した。

1 は塩化ナトリウム, 塩化カリウム, 無水ケイ酸, 混合物の分 解生成物で, 塩化ナトリウム, 塩化カリウムの等量混合物の回折 図と完全に一致する。

2 は炭酸マグネシウムの分解生成物でマグネシアの回折図 ${ }^{11,12)}$ と一致する。

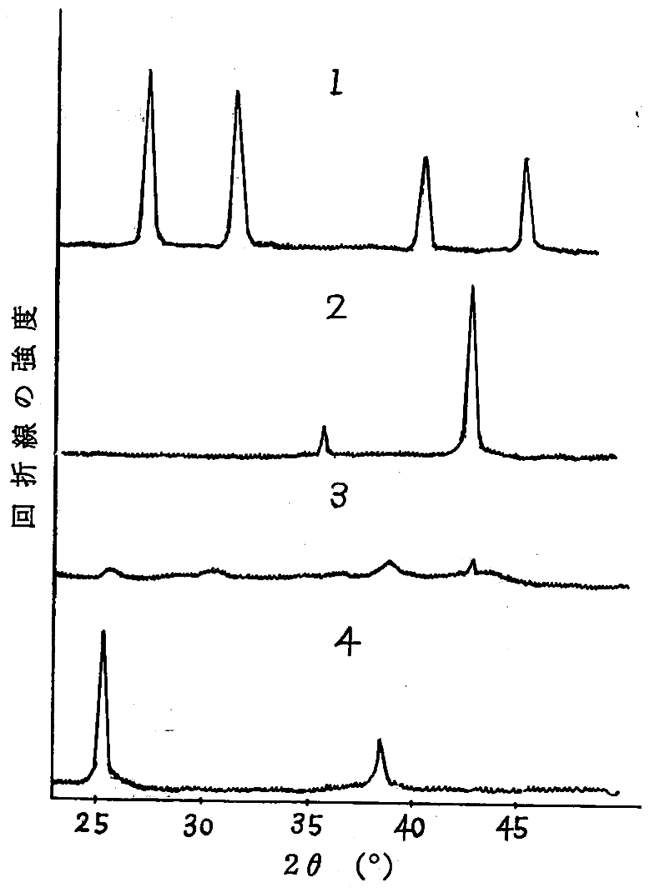

図 1 各種物質のX線回折図

1. $\mathrm{NaCl}, \mathrm{KCl}$ の混合物, $\mathrm{HF} \cdot \mathrm{HClO}_{4}$ 処理雉分解

2. $\mathrm{MgCO}_{3}, \mathrm{HF} \cdot \mathrm{HClO}_{4}$ 処理熱分解

3. $\mathrm{Al}(\mathrm{OH})_{3}: \mathrm{HF} \cdot \mathrm{HClO}_{4}$ 処理熱分解

4. Ti : HF. $\mathrm{HClO}_{4}$ 処理熱分解

11）久保輝一郎，加藤諴軌，X線回折に上る化学分析，日刊工 業新聞社 (1955).

12) A.S.T.M., X-Ray Diffraction Data File.
3 は水酸化マルミニウムの分解生成物であるが，非結晶性の化 合物であるので回折線は認められない。

4 はチタンの分解生成物でルチル11,12)の回折困と一致する。 ソーダガラスに比較的多量に含まれているカルシウムは上記の分 解方法で処理すると $\left.\mathrm{CaCl}_{2}, \mathrm{Ca}(\mathrm{OH})_{2} \mathrm{H}_{2} \mathrm{O}^{12}\right)$ の形の化合物の回 折図とほぼ一致するが吸湿性が大きく X線による.同定が困難であ った。

\section{$3 \cdot 2$ 吸湿性の化合物の除去}

ソーダガラスのように比較的多量にカルシウムを含有している 試料をフッ化水素酸-過塩素酸で処理するとカルシウムは吸湿性 の大きい $\mathrm{CaCl}_{2}, \mathrm{Ca}(\mathrm{OH})_{2} \cdot \mathrm{H}_{2} \mathrm{O}$ の形となり $\mathrm{X}$ 線による同定が困 難となったので吸湿性の除去について検討した。

シュウ酸カルシウム, シュウ酸ナトリウム, シュウ酸カリウム にそれぞれ塩酸を加兄て蒸発乾固して重量変化を測定した結果を 表 1 に示す。

表 1 、塩酸処理によるシュウ酸塩の重量変化

\begin{tabular}{|c|c|c|c|c|}
\hline 試 料 & 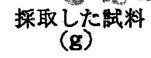 & $\underset{(\mathrm{m} l)}{\text { 添加 L㙁 }}$ & $\begin{array}{c}\text { 实測した重量 } \\
\text { (g) }\end{array}$ & 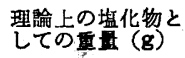 \\
\hline $\begin{array}{l}\text { シュゥ酸ナ } \\
\text { トリウ }\end{array}$ & $\begin{array}{l}0.5000 \\
0.5042\end{array}$ & $\begin{array}{l}4 \mathbf{N} 10 \\
6 \mathbf{N} 10\end{array}$ & $\begin{array}{l}0.4416 \\
0.4390\end{array}$ & $\begin{array}{l}0.4361 \\
0.4391\end{array}$ \\
\hline 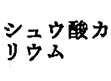 & $\begin{array}{l}0.5000 \\
0.5000 \\
0.5000\end{array}$ & $\begin{array}{r}6 \mathbf{N} 10 \\
10 \mathbf{N} 10 \\
12 \mathbf{N} 10\end{array}$ & $\begin{array}{l}0.4960 \\
0.4940 \\
0.4941\end{array}$ & $\begin{array}{l}0.4943 \\
0.4943 \\
0.4943\end{array}$ \\
\hline $\begin{array}{l}\text { シュウ䤑カ } \\
\text { ルシシ }\end{array}$ & $\begin{array}{l}0.3000 \\
0.5000\end{array}$ & $\begin{array}{l}6 \mathbf{N} 10 \\
6 \mathrm{~N} 10\end{array}$ & $\begin{array}{l}0.2995 \\
0.4997\end{array}$ & \\
\hline
\end{tabular}

表 1 の結果からわかるよ5にシュウ酸カルシウムは重量の変化 はなくシュウ酸塩の形で残存していると考えられる。シュウ酸ナ トリウム, シュウ酸カリウムは重量の変化があり, 重量の変化の 値から考察するとシュウ酸ナトリウムは $6 \mathrm{~N}$ 以上の塩酸で, シ ュウ酸カリウムは $10 \mathrm{~N}$ 以上の塩酸で定量的にそれぞれ, 塩化ナ トリウム，塩化カリウムの形になると考鼻られる。

塩化カルシウム, 塩化ナトリウムの混合物にシュウ酸および塩 酸を加えて乾固したのち $200 \sim 300^{\circ} \mathrm{C}$ に加熱したものおよび 450 $\sim 500^{\circ} \mathrm{C}^{13)}$ に加熱したものについてX線回折計を用いて組成分析 を行なった結果を図 2 に示した。1は混合物を塩酸シュウ酸で処 理し $200 \sim 300^{\circ} \mathrm{C}$ に加熱したものでシュウ酸カルシウムの回折線 は幾分弱いが，塩化ナトリウムとシュウ酸カルシウム以外の回折 線は認められなかった。2は1を 450〜 500C に加熱したもので 塩化ナトリウムの回折線は変化しないが他の回折線は消失し炭酸 カルシウムの回折線が生じている。

上記実験結果から過塩素酸ーブ化水素酸分解生成物をシュウ 酸, 塩酸で処理することによりカルシウムの塩化物のみをシュウ 酸塩にして吸湿性の少ないものにすることができた。

\section{$3 \cdot 3$ 板ガラス (ソーダガラス) の分解}

板ガラスをフッ化水素酸-過塩素酸で分解，蒸発乾固したのち $500 \sim 600^{\circ} \mathrm{C}$ で熱分解した生成物，おるよ゙この生成物にシュウ酸， 塩酸を加えて蒸発乾固し $200 \sim 300^{\circ} \mathrm{C}$ に加熱した生成物のX線回 折図を図 3 に示した。

1 は熱分解したままの分解生成物で吸湿性が大きく，塩化ナト リウム, 塩化カリウムの回折線のほかに $\mathrm{Ca}(\mathrm{OH})_{2} \cdot \mathrm{CaCl}_{2} \cdot \mathrm{H}_{2} \mathrm{O}$ の回折線と一致する化合物が存在して怙り，かつ，この化合物の $3.18 \AA$ の強い回折線は塩化カリウムの $3.14 \AA$ の回折線と近接 しているのでカリウムの定量が困難となる。

2は; この分解生成物をシュウ酸，塩酸で処理したもので，

13）宗宮, 平野, 工化 34, 1003 (1931). 


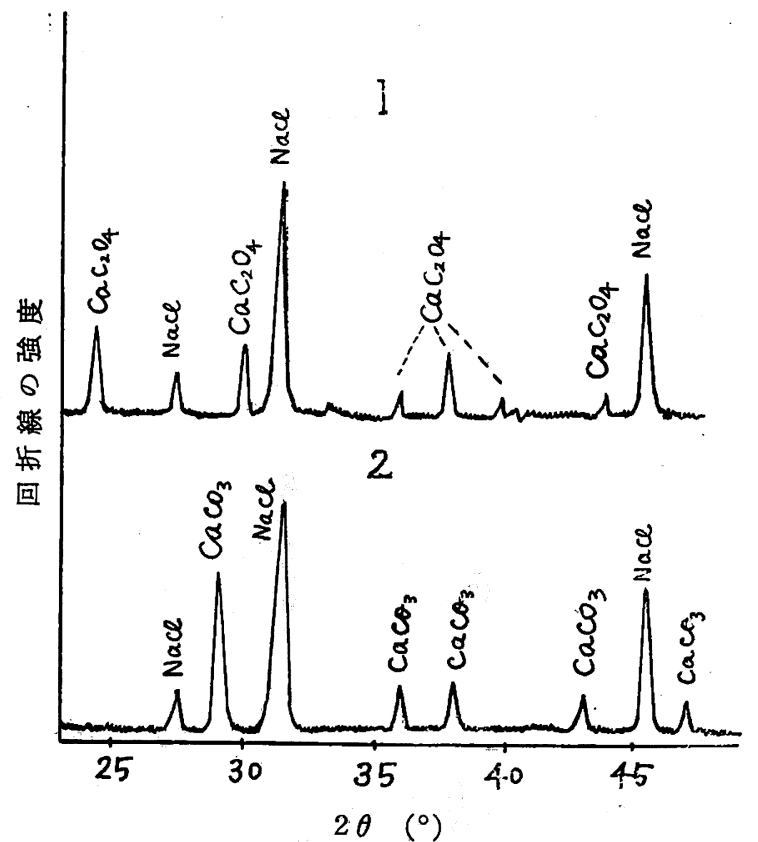

図 $2 \mathrm{NaCl}, \mathrm{CaCl}_{2}$ 混合物のシュウ酸, 塩酸分解生 成物の $\mathrm{X}$ 線回折図

1. $\mathrm{NaCl}, \mathrm{CaCO}_{3}$ の混合物 $(\mathrm{COOH})_{2}, \mathrm{HCl}$ 处理 $200 \sim 300^{\circ} \mathrm{C}$ 加繁 2. $450 \sim 500^{\circ} \mathrm{C}$ 加急

$\mathrm{Ca}(\mathrm{OH})_{2} \cdot \mathrm{CaCl}_{2} \cdot \mathrm{H}_{2} \mathrm{O}$ の回折線は消失しシュウ酸カルシウムの 回折線が認められ，かつ吸湿性はなくなった。

板ガラスのように多量のカルシウムを含有する試料はフッ化水 素酸一過塩素酸で処理し, 熱分解したのちさらにシュウ酸および $10 \mathrm{~N}$ 以上の塩酸で処理する必要がある。

3.4 多量のアルミニウムを含有する硬質カラス，長石の分解 硬質ガラス，長石を板ガラスと同様に処理した分解生成物をX 線回折計によって調べた結果を図 4 に示した。1 は硬質ガラスを フッ化水素酸-過塩素酸処理したもので多量のアルミニウムは $\mathrm{Na}_{3} \mathrm{AlF}_{6}, \mathrm{Na}_{2} \mathrm{KAlF}_{6}$ ，のような化合物となり，ただ単に過塩素酸 で処理しただけではこれらのアルミニウムのフッ素化合物は完全 に除去出来なかった。 2 はこの分解物にさらに過剩の過塩素酸を

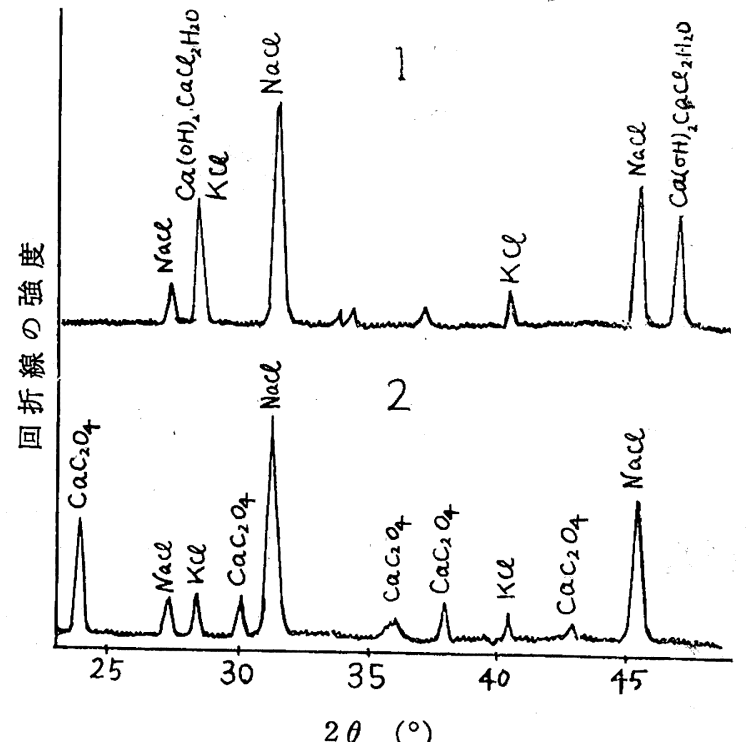

図 3 板ガラス分解生成物のX線回折図 1:ソーダガラスを $\mathrm{HClO}_{4}$ ， $\mathrm{HF}$ で分解，㠇分解 $2: 1$ を $\mathrm{C}_{2} \mathrm{H}_{2} \mathrm{O}_{4}, \mathrm{HCl}$ 处理

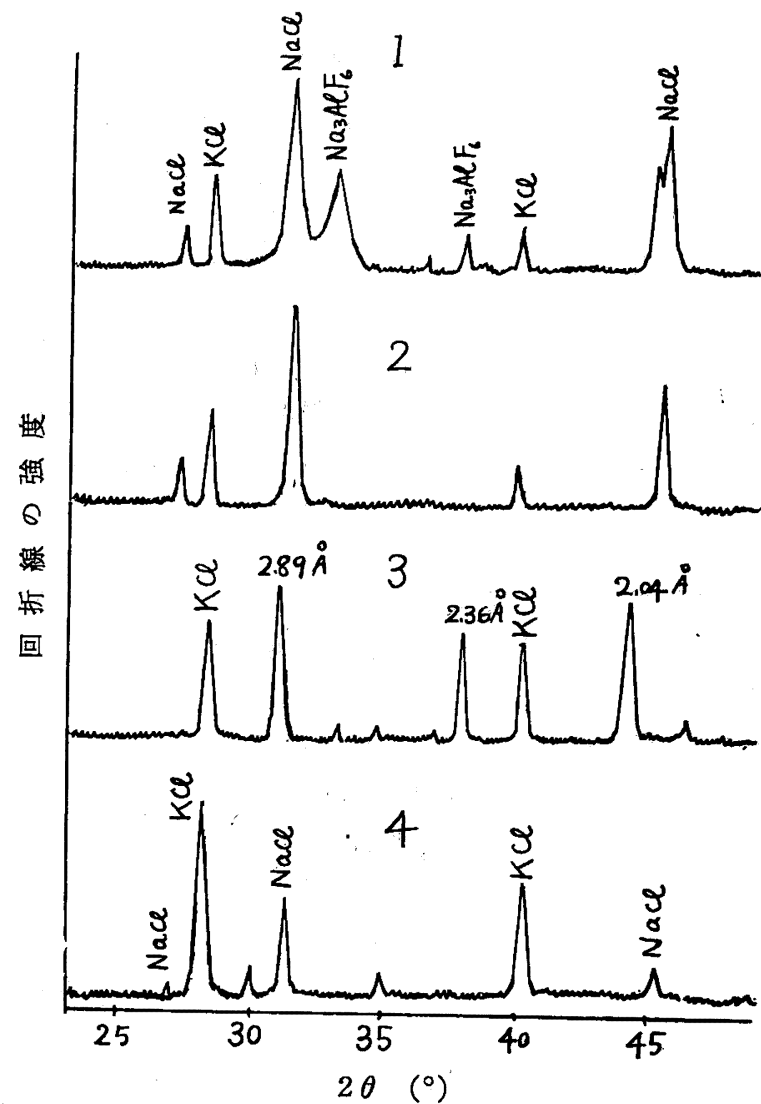

図 4 硬質ガラス, 長石, 分解生成物の $\mathrm{X}$ 線回折図

1. 硬留ガラス $\mathrm{HF}, \mathrm{HClO}_{4}$ 処理繁分解 2. 1 を $\mathrm{HCl}$ 処理

3. 長石 $\mathrm{HF}, \mathrm{HClO}_{4}$ 处理整分解 $\quad$ 4. 3 を $\mathrm{HCl}$ 处理

加兄て蒸発乾固したものの回折図で $\mathrm{Na}_{3} \mathrm{AlF}_{6}$ の回折線は完全に 消失している。

3 は長石を 2 と同様に処理したものの回折図で塩化カyウムの 回折線の他に $2.89 \AA, 2.36 \AA$, 2.04 $\AA$, の比較的強い回折線が 認められる。

4 は 3 の生成物に濃塩酸を加えて蒸発乾固し $200 \sim 300^{\circ} \mathrm{C}$ に加 熱したものの回折図で $2.89 \AA ， 2.36 \AA ， 2.04 \AA$, の回折線は消 失し, 塩化カリウム, 塩化ナトリウムの回折線のみとなった。

\section{4 試料の分解方法}

上記実験結果から試料の分解方法をつぎのように決定した。 細粉試料 1〜2g を白金蒸発皿にとり，少量の水でらる括し過 塩素酸 $(60 \%) 15 \mathrm{ml}$, フッ化水素酸 $10 \mathrm{ml}$ を加えて加熱分解し たのち砂具上で引続さ加熱してケイ酸および過剩の過塩素酸を揮 散させ乾固する。

（1）板ガラスのよ5に多量のカルシウムを含有している試料 は $500^{\circ} \mathrm{C}$ に加熱したマッフル炬に入れ約 $600^{\circ} \mathrm{C}$ まで加熱し過塩素 酸塩を熱分解する。つぎにシュウ酸溶液 (10\%) 3〜 $5 \mathrm{ml}$, 塩酸 $10 \mathrm{~m} l$ を加えてふたたび蒸発乾固したのち $200 \sim 300^{\circ} \mathrm{C}$ に約 30 分間加熱する。

（2）長石，硬質ガラスのように多量のアルミニウムを含有す る試料はフッ化水素酸, 過塩素酸を加えて蒸発乾固したのち, ふ たたび過熄素酸 $10 \mathrm{ml}$ を加えて蒸発乾固して過塩素酸を揮散さ せ， $500^{\circ} \mathrm{C}$ に加熱したマッフル炉に入れ，600 C まで加熱し過㙁 素酸塩を分解したのち，塩酸 $10 \mathrm{ml}$ を加兄て蒸発乾固し 200〜 $300^{\circ} \mathrm{C}$ に約 30 分間加熱する。 


\section{$5 \mathrm{X}$ 線回折計による定量方法}

ソーダガラス，硬質ガラス，長石のX線回折困からわかるよう に石英あるいはシッ化バリウムを内標準物質 ${ }^{14)}$ とて分解生成物 中の塩化ナトリウム, 塩化カリウムの定量がでさる。またX線は 多量の鉄を含有している試料にも適用できるように $\mathrm{CoK}_{\alpha}$ を使 用することにした。

\section{$5 \cdot 1$ 検量楾（比例定数の測定）}

塩化ナトリウム，塩化カリウムを標準物質とし，石英あるいは フッ化バリウムを内標準物質，酸化マグネシウムを希釈剂として 標準混合物を作製した。

これらの物質特に塩化カリウム，石英はX線回折法による定量

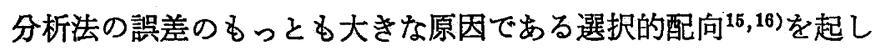
やすいので上記標準物質を混合したのちメノウ乳鉢で約 30 分間 粉砕した。

\section{$5 \cdot 2$ 検量線の作成}

上記方法で作製した混合物について $\mathrm{NaCl}: d=2.82 \AA ⿻ \mathrm{KCl}$ : $d=3.14 \AA$ 吅回折線と内標準物質 $\mathrm{SiO}_{2}: d=3.36 \AA$ ， あるいは $\mathrm{BaF}_{2}: d=3.58 \AA$ の回折線との強度比と各成分量 (wt $\%$ ) と の関係を求めて図 5 に示すよ5な関係が得られた。 $\mathrm{NaCl}(d=$ $2.82 \AA), \mathrm{BaF}_{2}\left(d=3.58 \AA\right.$ を を用いて $I_{\mathrm{NaCl} /} / I_{\mathrm{BaF}_{2}}=K W_{\mathrm{NaCl}} /$ $W_{\mathrm{BaF}_{2}}$ を求めると $K_{\mathrm{BaF}_{2} 3_{38}}^{\mathrm{NaCl}_{3} 82}=0.77$ となり, また同様の関係か ら $K_{\mathrm{BaF}_{2} 3^{3.88}}^{\mathrm{KCls.14}}=0.79$ となる。

$\mathrm{NaCl}(d=2.82 \AA), \mathrm{SiO}_{2}\left(d=3.36 \AA\right.$ 年用いて $K_{\mathrm{SiO}_{3} 8.36}^{\mathrm{NaCl2}}=$ 1.09 となる。 $\mathrm{KCl}$ の場合は図 6 からわかるよ5に幾分わん曲し た線になる。

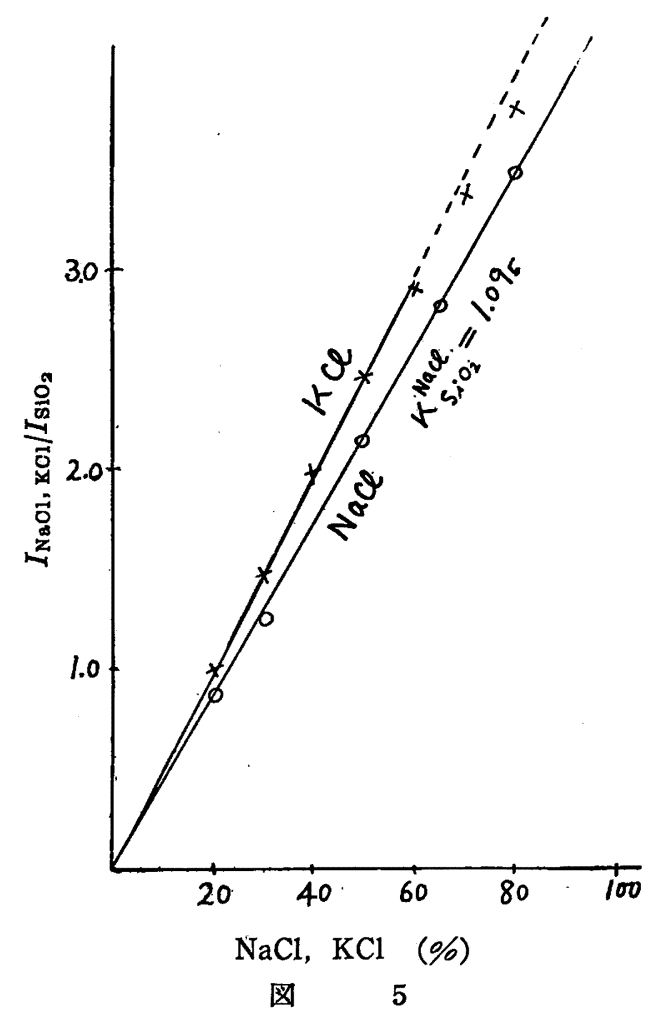

14) . H. P. Klug, L. E. Alexander, "X-Ray Diffraction, Procedures for Polycrystalline and Amorphous Materials" (1954).

15) 橋詰, 萩野, 小林, 分析化学 7, 287 (1958).

16) 平野, 贵家, 分析化学 8, 495 (1959).

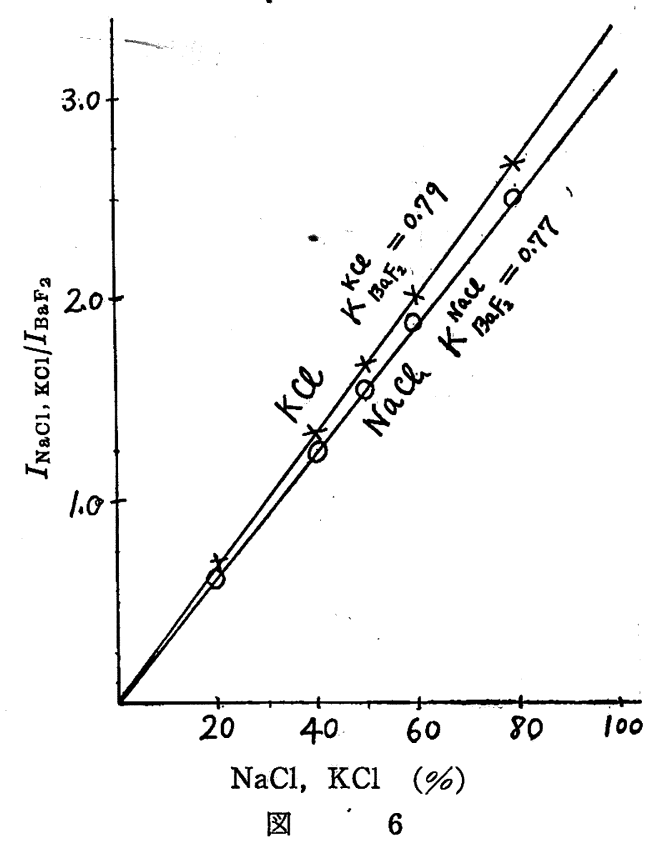

内標準物質としてはフッ化バリウム，石英，のいずれも用いら れるが石英は選択的配向性のためフッ化バリウムに比較して定量 值にばらつきが多かった。

表 2 混合試料の定量結果

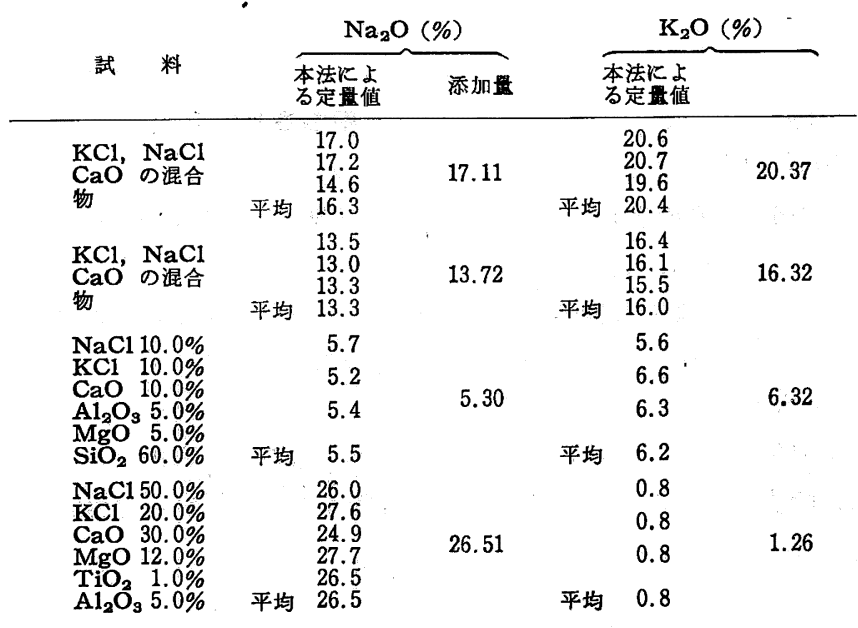

表 3 各種试料の定量結果

\begin{tabular}{|c|c|c|c|c|c|c|}
\hline \multirow[b]{2}{*}{ 試 料 } & \multicolumn{3}{|c|}{$\mathrm{Na}_{2} \mathrm{O}(\%)$} & \multicolumn{2}{|c|}{$\mathrm{K}_{2} \mathrm{O}(\%)$} & \multirow{2}{*}{$\begin{array}{c}\text { 他の成分 } \\
(\%)\end{array}$} \\
\hline & $\begin{array}{l}\text { 本法烧量 } \\
\text { る値 }\end{array}$ & & $\begin{array}{l}\text { 华爱 } \\
\text { 分析値 }\end{array}$ & $\begin{array}{l}\text { 本法炡よ } \\
\text { る是量値 }\end{array}$ & $\begin{array}{l}\text { 货析学 } \\
\text { 值 }\end{array}$ & \\
\hline 板ガラス & $\begin{array}{r}14.4 \\
14.4 \\
13.1 \\
14.2 \\
13.5 \\
\text { 平均13.9 }\end{array}$ & & $14.00^{*}$ & & & $\begin{array}{ll}\mathrm{SiO}_{2} & 70.76 \\
\mathrm{Al}_{2} \mathrm{O}_{9} & 1.30 \\
\mathrm{Fe}_{2} \mathrm{O}_{3} & 0.20 \\
\mathrm{TiO}_{2} & 0.04 \\
\mathrm{CaO} & 8.33 \\
\mathrm{MgO} & 4.23\end{array}$ \\
\hline 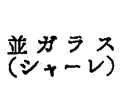 & $\begin{array}{r}13.7 \\
13.9 \\
13.2 \\
\text { 平均13.6 }\end{array}$ & & $\begin{array}{l}14.0 \\
14.2 \\
14.1\end{array}$ & $\begin{array}{r}0.4 \\
0.4 \\
\text { 平均 } 0.4\end{array}$ & $\begin{array}{r}0.50 \\
0.49 \\
\text { 平均 } 0.50\end{array}$ & $\begin{array}{lr}\mathrm{SiO}_{2} & 72.48 \\
\mathrm{R}_{2} \mathrm{O}_{3} & 1.50 \\
\mathrm{CaO} & 10.10 \\
\mathrm{MgO} & 0.26\end{array}$ \\
\hline 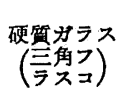 & $\begin{array}{r}3.7 \\
3.8 \\
3.9 \\
\text { 平均 } 3.8\end{array}$ & 平均 & $\begin{array}{l}3.9 \\
3.9 \\
3.9\end{array}$ & $\begin{array}{r}0.7 \\
0.7 \\
0.7 \\
\text { 平均 } 0.7\end{array}$ & $\begin{array}{r}0.8 \\
0.8 \\
\text { 平均 } 0.8\end{array}$ & $\begin{array}{lr}\mathrm{SiO}_{2} & 79.39 \\
\mathrm{R}_{2} \mathrm{O}_{3} & 2.98 \\
\mathrm{CaO} & 0.38\end{array}$ \\
\hline " & $\begin{array}{r}4.3 \\
4.1 \\
4.3 \\
\text { 平均 } 4.2\end{array}$ & 平均 & $\begin{array}{l}4.15^{* *} \\
4.16 \\
4.16\end{array}$ & $\begin{array}{r}0.7 \\
0.8 \\
0.7 \\
\text { 平均 } 0.8\end{array}$ & $\begin{array}{r}0.8 \\
0.8 \\
\text { 平均 } 0.8\end{array}$ & $\begin{array}{lr}\mathrm{SiO}_{2} & 79.51 \\
\mathrm{R}_{2} \mathrm{O}_{3} & 3.01 \\
\mathrm{CaO} & 0.32\end{array}$ \\
\hline & $\begin{array}{r}1.2 \\
1.3 \\
1.1 \\
\text { 平均 } 1.2\end{array}$ & 平均 & $\begin{array}{l}1.5 \\
1.5 \\
1.6 \\
1.5\end{array}$ & $\begin{array}{r}10.9 \\
10.8 \\
10.8 \\
\text { 平均10.8 }\end{array}$ & $\begin{array}{r}11.5 \\
11.6 \\
\text { 平均11.6 }\end{array}$ & $\begin{array}{ll}\mathrm{SiO}_{2} & 64.26 \\
\mathrm{R}_{2} \mathrm{O}_{3} & 19.48 \\
\mathrm{CaO} & 0.34\end{array}$ \\
\hline
\end{tabular}

$\mathrm{Na}_{2} \mathrm{O}, \mathrm{K}_{2} \mathrm{O}$ 性光光光度法に上って定量した。

* N社の社内橾望武料 $* *$ ローレンススミス法 


\section{6 混合試料の定量結果}

塩化ナトリウム, 塩化カリウム, 酸化カルシウムの混合物, 水 化アルミニウム, 塩化ナトリウム, 塩化カリウムの混合物に無水 ケイ酸を加えた混合試料およびガラスの組成に近い混合物を前記 分解方法で処理したのちX線回折計を用いて塩化ナトリウム，塩 化カリウムの定量を行なって計算値と比較して表 2 亿示す。

表 2 の結果からわかるよ5に本法による定量結果と計算值とは 一致している。

\section{7 実際試料の定量結果}

板ガスラ，並ガラス（シャーレ），硬質ガラス（三角フラスコ） 和よび長石を試料としてナトリウム，カリウムの定量を行なって
化学分析による値と比較して表 3 のような結果を得た。

表 3 の結果からわかるように板ガラス, 硬質ガラス中のナトリ ウム，カリウムの定量値は重量法执よび炎光光度法による結果と よく一致した。アルミニウム含有量の多い長石の場合には幾分低 値を示した。この原因はX線回折の結果から考察してアルミニウ ム含有量の多い試料は塩化カリウムの結晶の粒度が小さいためと 考えられる。

以上の結果から考察してケイ酸塩, ガラス等の試料中のナトリ ウム, カリウムを塩化物の形としX線回折計を用いてナトリウム カリウムの同時定量が出来た。

本法は従来行なわれている重量分析方法に比較して幾分精度は 劣るが操作が簡単であり比較的短時間にナトリウム, カリウムの 同時定量が出来る。

\title{
配 合 化 成 肥 料 の 構 成 鉱 物
}

（昭 和 35 年 9 月 5 日 受 理)

\author{
安 藤 淳 平・松 野 清 一*
}

\begin{abstract}
過リン酸石灰に硫安，塩化カリを配合しアンモニア化，造粒してつくる化成肥料について，その製造工程間の鉱物の变 化および各工場製品の鉱物組成をX線定量によって検討し明らかにした。造粒, 乾燥の工程で原料塩類間に著しい変化が 起り, $\mathrm{N}: \mathrm{P}_{2} \mathrm{O}_{5}: \mathrm{K}_{2} \mathrm{O}$ が 8-8-5, 6-9-6, 8-7-8 などの代表的な組成の肥料では硫安, 塩化カリはほとえど消失して塩化 アンモン, リン酸一カリウムアンモニウム，カリウムアンモニウムシンゲナイトなどを生成する。シンゲナイトは乾嬠工 程の初期に多量に生成し, 乾燥が進むにしたがって一部が熱分解を起す。この分解生成した無水セッコウ, 硫安および原 料中の少量の未反応の無水セッコウ，硫安などは，堆積放置中に再びシンゲナイトを形成する。この際のシンゲナイトの. 生成, 怙よびこれに伴なって肥料中の水分が結晶水となって遊離水分が減少することにより, 溶解塩類が析出して化成肥 料の粒のすきまを埋めるなどの作用が; 化成肥料固結の大きな原因と考える。
\end{abstract}

\section{1 緒 言}

過りン酸石灰に硫安，塩化カリをさまさまの割合に配合し，過 リン酸中の遊離リン酸を中和する程度のアンモニア化を行ない, 水を加兄て造粒し乾燥する方式のいわゆる配合化成肥料が，最近 はなはだ多種, 多量泟生産されている。このような配合化成の場 合は以前のリン鉱石飞硫安, 塩化カリなどを配合して硫酸を加兄 る，いわゆるム口化成肥料の場合とは異なって，原料塩があまり 变化せず製品中に残るものと一般に考光られている。従来これに 関する研究はほとんぞなく, 池野ら ${ }^{1)}$ が部分的に触れているにす ぎない。

著者らはこの製造過程に著しい变化が起ることを認め, 製造中 の各段階掞よび製品中の各鉱物の量をX線で定量して変化の過程 を明らかにした。また製造就よび使用の際にしばしば問題となる 製品の固結その他の現象についても知見を得たので要点を報告す る。

\section{2 実験および考察}

\section{$2 \cdot 1$ 製品中の鉱物の形態と生成反応}

三工場より製品の送付を受け，構成鉱物をX線で調べた。原料 は過りン酸石灰（すなわち $\mathrm{CaSO}_{4}, \mathrm{Ca}\left(\mathrm{H}_{2} \mathrm{PO}_{4}\right) \cdot \mathrm{H}_{2} \mathrm{O}$, 少量の

* 中央大学工学部 : 東京都文京区元町.

1) 池野, 下村, 工化 63, 78 (1960).
$\mathrm{CaSO}_{4} \cdot 1 / 2 \mathrm{H}_{2} \mathrm{O}$ その他よりなる)，硫安，塩化カリであるが，製 品中の鉱物情 1 亿示すよ5 亿カリウムアンモニウムシンゲナイ 卜（すなかちカリウムシンゲナイト $\mathrm{K}_{2} \mathrm{SO}_{4} \cdot \mathrm{CaSO}_{4} \cdot \mathrm{H}_{2} \mathrm{O}$ とアンモ ニウムシンゲナイト $\left(\mathrm{NH}_{4}\right)_{2} \mathrm{SO}_{4} \cdot \mathrm{CaSO}_{4} \cdot \mathrm{H}_{2} \mathrm{O}$ の固溶体となった もの), リン酸一カリウムアンモニウム（すなわちリン酸一カリ ウムとリン酸アンモニウムの固溶体）および塩化アンモンが主で あって，原料中の鉱物としては無水セッコウが若干残っている程 度で，リン酸一石灰は認められず，塩化カリ，硫安もほとんど残 っていない。 $\mathrm{N}-\mathrm{P}_{2} \mathrm{O}_{5}-\mathrm{K}_{2} \mathrm{O}$ 比が 6-9-6 のような過りン酸石灰の 多い配合肥料の場合は，無水セッコウがかなり多く残り、3-10-10 のよ5にカリ分の特に多い配合では若干の塩化カリが残る。

これらの塩類は次のような反応沉ょって生成または消失すると 考光る。

$$
\begin{aligned}
& \mathrm{Ca}\left(\mathrm{H}_{2} \mathrm{PO}_{4}\right)_{2} \cdot \mathrm{H}_{2} \mathrm{O}+\left(\mathrm{NH}_{4}\right)_{2} \mathrm{SO}_{4} \\
& =2 \mathrm{NH}_{4} \mathrm{H}_{2} \mathrm{PO}_{4}+\mathrm{CaSO}_{4}+\mathrm{H}_{2} \mathrm{O} \\
& \left(\mathrm{NH}_{4}\right)_{2} \mathrm{SO}_{4}+\mathrm{CaSO}_{4}+\mathrm{H}_{2} \mathrm{O}=\left(\mathrm{NH}_{4}\right)_{2} \mathrm{SO}_{4} \cdot \mathrm{CaSO}_{4} \cdot \mathrm{H}_{2} \mathrm{O} \\
& 2 \mathrm{KCl}+\left(\mathrm{NH}_{4}\right)_{2} \mathrm{SO}_{4}=\mathrm{K}_{2} \mathrm{SO}_{4}+2 \mathrm{NH}_{4} \mathrm{Cl} \\
& \mathrm{K}_{2} \mathrm{SO}_{4}+\mathrm{Ca}\left(\mathrm{H}_{2} \mathrm{PO}_{4}\right)_{2} \cdot \mathrm{H}_{2} \mathrm{O}=2 \mathrm{KH}_{2} \mathrm{PO}_{4}+\mathrm{CaSO}_{4}+\mathrm{H}_{2} \mathrm{O} \\
& \mathrm{K}_{2} \mathrm{SO}_{4}+\mathrm{CaSO}_{4}+\mathrm{H}_{2} \mathrm{O}=\mathrm{K}_{2} \mathrm{SO}_{4} \cdot \mathrm{CaSO}_{4} \cdot \mathrm{H}_{2} \mathrm{O} \\
& k \mathrm{KH}_{2} \mathrm{PO}_{4}+l \mathrm{NH}_{4} \mathrm{H}_{2} \mathrm{PO}_{4} \\
& \longrightarrow \text { リン酸一カリウムアンモニウム固溶体 } \\
& m\left[\mathrm{~K}_{2} \mathrm{SO}_{4} \cdot \mathrm{CaSO}_{4} \cdot \mathrm{H}_{2} \mathrm{O}\right] \\
& +n\left[\left(\mathrm{NH}_{4}\right)_{2} \mathrm{SO}_{4} \cdot \mathrm{CaSO}_{4} \cdot \mathrm{H}_{2} \mathrm{O}\right] \longrightarrow \text { 固溶体 }
\end{aligned}
$$

